\section{Production and Postharvest Assessment of Tropical Pumpkin Flowers Harvested for Consumption}

\author{
Kathina Toro-Vélez ${ }^{1}$, Rosa Chávez-Jáuregui ${ }^{1,2}$, \\ Linda Wessel-Beaver ${ }^{2}$, and Bryan Brunner ${ }^{2}$
}

AdDitIONAL INDEX wORDs. chemical properties, Cucurbita moschata, modified atmosphere packaging, nutrition, sensory evaluation, shelf life

Summary. Consumption of staminate (male) flowers of squash and pumpkin (Cucurbita sp.) has generally been limited to summer squash (Cucurbita pepo), a species of temperate regions or highland tropical environments. In the lowland tropics of the Caribbean Basin, tropical pumpkin (Cucurbita moschata) is better adapted and more widely grown. We evaluated flower production in Lajas, Puerto Rico, and postharvest attributes (shelf life, chemical and nutritional properties, sensory quality) of flowers of four tropical pumpkin and two summer squash cultivars. Tested cultivars varied slightly among experiments. Passive and active modified atmosphere packaging (MAP) were compared. For passive MAP, packages were sealed without further intervention. Under active MAP, packages were adjusted to $6 \%$ to $7 \%$ oxygen $\left(\mathrm{O}_{2}\right)$ and $12 \%$ to $13 \%$ carbon dioxide $\left(\mathrm{CO}_{2}\right)$ during sealing. Sensory quality of fresh and canned tropical pumpkin flowers was evaluated by panelists. Production ranged from 1.8 to 4.0 flowers/plant per day. Flower weight and length were up to $50 \%$ greater in tropical pumpkin compared with summer squash. Packaged flowers turned more orange but with less color saturation as they aged. In active MAP packages, decreases in $\mathrm{O}_{2}$, and increases in $\mathrm{CO}_{2}$ observed after 5 days were small or not significant compared with initially established atmospheres at day 0 . Storage temperature generally had no effect on changes in $\mathrm{O}_{2}$ and $\mathrm{CO}_{2}$. Packaged flowers lost about $27 \%$ of their initial weight after 5 days. Type of MAP had no consistent effect on the appearance of packaged flowers. Storing flowers at $5{ }^{\circ} \mathrm{C}$ often improved appearance compared with storage at $10^{\circ} \mathrm{C}$. The rate of deterioration was slower in packaged flowers of tropical pumpkin compared with summer squash, but by day 6 the poor appearance of flowers of all cultivars made them unmarketable. Compared with fresh flowers, packaged flowers stored for $\mathbf{5}$ days exhibited a decrease in soluble solids, total acidity, ascorbic acid, antioxidant capacity, and total phenolics, and generally an increase in $\mathrm{pH}$. Beta-carotene often increased in stored flowers although this varied by cultivar. Storage temperature and type of MAP had inconsistent effects on chemical attributes of stored flowers. Panelists rated fresh flowers as "like moderately" to "like very much" for texture, taste, and overall acceptability, whereas canned flowers were rated as "like moderately" for overall acceptability. Male flowers of tropical pumpkin are suitable for human consumption but deterioration after $\mathbf{5}$ days of storage limits their market potential unless better packaging methods are developed. Canned tropical pumpkin flowers may be an alternative to packaged flowers. woman offers a basket of both male and female flowers for sale (Paris and Janick, 2004). In Mexico, squash and pumpkin flowers are used in soups, quesadillas, tamales, and desserts (Asiain-Morales et al., 2008), and fried squash blossoms are popular in Italy (Milc et al., 2016). Sotelo et al. (2007) found that squash flowers had no antinutritional factors and that their amino acid profile was generally superior to that of the "ideal protein" as defined by the World Health Organization. Drava et al. (2020) found that potentially toxic elements in C. pepo and Cucurbita moschata were present at levels well below that of concern.

There are two subspecies of $C$. pepo. The market classes pumpkin, zucchini, cocozelle, and vegetable marrow belong to C. pepo ssp. pepo, while $C$. pepo ssp. ovifera (synonym: C. реро ssp. texana) corresponds to the acorn, scallop, straightneck, and crookneck types (Umiel et al., 2007). Each subspecies includes both winter and summer squash. Market classes have not been defined for other squash and pumpkin species. Umiel et al. (2007) compared flowers of 21 accessions of various market classes of $C$. pepo and found that flowers of $C$. реро ssp. pepo had, on average, a firmer texture and were longer than flowers of C. pepo ssp. ovifera. However, they noted a great degree of variability, especially within C. pepo ssp. pepo. Although we have not seen subspecies specified in the literature concerning edible squash and pumpkin flowers, it is likely that flowers are more often harvested from $C$. pepo ssp. pepo than from the generally smaller-flowered C. реро ssp. ovifera. However, there
S quash and pumpkin are common cated species in the genus Cucurbita. In scientific and popular literature, the species is often not clear because "squash" and "pumpkin" do not refer to a particular species. However, we believe that consumption of male flowers within the genus has often been limited to summer squash (Cucurbita pepo). Flowers of summer squash were depicted as being used for culinary purposes as early as 1580 in Vicenzo Campi's painting The Fruit Seller in which a young names applied to five domesti-

\begin{tabular}{llll}
\hline $\begin{array}{l}\text { Units } \\
\begin{array}{l}\text { To convert U.S. to SI, } \\
\text { multiply by }\end{array}\end{array}$ & U.S. unit & SI unit & $\begin{array}{l}\text { To convert SI to U.S., } \\
\text { multiply by }\end{array}$ \\
\hline 0.4047 & $\mathrm{acre}(\mathrm{s})$ & $\mathrm{ha}$ & 2.4711 \\
29,574 & $\mathrm{fl} \mathrm{oz}$ & $\mu \mathrm{L}$ & $3.3814 \times 10^{-5}$ \\
29.5735 & $\mathrm{fl} \mathrm{oz}$ & $\mathrm{mL}$ & 0.0338 \\
0.3048 & $\mathrm{ft}$ & $\mathrm{m}$ & 3.2808 \\
3.7854 & $\mathrm{gal}$ & $\mathrm{L}$ & 0.2642 \\
2.54 & $\mathrm{inch}(\mathrm{es})$ & $\mathrm{cm}$ & 0.3937 \\
25.4 & $\mathrm{inch}(\mathrm{es})$ & $\mathrm{mm}$ & 0.0394 \\
0.0254 & $\mathrm{mil}(\mathrm{s})$ & $\mathrm{mm}$ & 39.3701 \\
28.3495 & $\mathrm{Oz}$ & $\mathrm{g}$ & 0.0353 \\
0.0001 & $\mathrm{ppm}$ & $\mathrm{g} / 100 \mathrm{~g}$ & 10,000 \\
0.1 & $\mathrm{ppm}$ & $\mathrm{mg} / 100 \mathrm{~g}$ & 10 \\
0.1 & $\mathrm{ppm}$ & $\mathrm{mg} / 100 \mathrm{~mL}$ & 10 \\
1 & $\mathrm{ppm}$ & $\mathrm{mg} \cdot \mathrm{L}^{-1}$ & 1 \\
$\left({ }^{\circ} \mathrm{F}-32\right) \div 1.8$ & ${ }^{\circ} \mathrm{F}$ & ${ }^{\circ} \mathrm{C}$ & $\left({ }^{\circ} \mathrm{C} \times 1.8\right)+32$
\end{tabular}

Horllechnology · April 2022 32(2) 
are exceptions: in Italy, squash flowers are often fried, and smaller flowers, more typical of C. pepo ssp. ovifera, are preferred (Milc et al., 2016).

Summer squash flowers have traditionally been sold in open boxes or baskets in farmers' markets. Better postharvest and packaging techniques would likely be needed for sales in supermarkets. The short shelf life of squash/pumpkin flowers limits their marketing, therefore there is a need to identify ways to expand shelf ife by maintaining quality and inhibiting undesirable microbial growth (Allende et al., 2006; Aquino-Bolaños et al., 2013). The use of controlled atmosphere storage (CAS) and MAP offer possible solutions (Kader and Saltveit, 2002a; Tripathi and Tuteja, 2007). In CAS, gas composition, particularly of oxygen $\left(\mathrm{O}_{2}\right)$ and carbon dioxide $\left(\mathrm{CO}_{2}\right)$, is closely regulated throughout the storage period. Active MAP initially replaces the air in the package with a specified gas mixture, but over time, internal atmosphere composition changes due to physiological processes in the tissues of the enclosed product. In passive MAP, a package is sealed without further intervention but, again, internal gas composition will change over time. Both CAS and MAP are expected to reduce respiration and delay senescence, but the lowest respiration rate would be expected with CAS, followed by active and then passive MAP.

Villalta et al. (2004) evaluated flowers of 'Dixie' summer squash (a straightneck type) at the bud stage packaged into polystyrene clamshell packages. Flowers maintained

Received for publication 14 Sept. 2021. Accepted for publication 5 Jan. 2022.

Published online 16 February 2022.

${ }^{1}$ Food Science and Technology Program, University of Puerto Rico at Mayagüez, P.O. Box 9000, Mayagüez, PR 00681-9000

${ }^{2}$ Department of Agroenvironmental Sciences, University of Puerto Rico at Mayagüez, P.O. Box 9000, Mayagüez, PR 00681-9000

This work was supported by Hatch project accession no. 1003571 from the U.S. Department of Agriculture, National Institute of Food and Agriculture, and the University of Puerto Rico Agricultural Experiment Station. This paper is from a thesis submitted by Kathina Toro-Vélez in partial fulfillment of the requirements for an M.S. degree. The authors thank the reviewers whose constructive comments helped to considerably improve this manuscript.

R.C.-J. is the corresponding author. E-mail: rosa. chavez@upr.edu.

This is an open access article distributed under the CC BY-NC-ND license (https://creativecommons. org/licenses/by-nc-nd/4.0/).

https://doi.org/10.21273/HORTTECH04955-21 a marketable appearance for $7 \mathrm{~d}$ at 2.5 and $5{ }^{\circ} \mathrm{C}$. López Pérez (2007) tested squash/pumpkin flowers (species or cultivar not specified; photographs suggest they were summer squash) packaged into plastic-wrapped low-density polyethylene trays and plastic bags. Flowers maintained marketable quality for up to $9 \mathrm{~d}$ at $8^{\circ} \mathrm{C}$ and for up to $12 \mathrm{~d}$ at $4^{\circ} \mathrm{C}$. Packaging method had no effect on flower longevity. Asiain-Morales et al. (2008) evaluated squash/pumpkin flowers (species not specified) at bud (unopened) stage under active MAP. A controlled atmosphere of $11 \%$ to $15 \% \mathrm{CO}_{2}, 5 \% \mathrm{O}_{2}$, and $80 \%$ to $83 \%$ nitrogen $\left(\mathrm{N}_{2}\right)$ maintained flowers in marketable condition up to $16 \mathrm{~d}$, whereas flowers packaged without $\mathrm{CO}_{2}$ lasted less than $10 \mathrm{~d}$.

Tropical pumpkin (C. moschata) is grown around the world in the humid lowland tropics (elevations below $1000 \mathrm{~m}$ ) and is usually consumed as a mature fruit or "winter squash." It is widely cultivated and consumed in the Caribbean, including Puerto Rico. To distinguish between temperate and tropical cultivars of $C$. moschata, we use the convention of referring to tropical cultivars of this species as "tropical pumpkin." In Puerto Rico, tropical pumpkin is the second most important vegetable crop after tomato [Solanum lycopersicum (Instituto de Estadísticas, 2015)]. The Agricultural Experiment Station (AES) of the University of Puerto Rico, Mayagüez Campus (UPRM), has supported a tropical pumpkin breeding program for many years. In Puerto Rico and the region in general, there is growing interest in using local products in unique ways to satisfy the increasingly sophisticated palates of local consumers and to offer the tourist industry interesting dishes based on local products.

Here we evaluate tropical pumpkin flower production in the field in Puerto Rico as well as postharvest quality (shelf life and chemical and nutritional properties) of flowers subjected to passive and active MAP. In addition, we evaluate the reaction of sensory panel participants to fresh and canned tropical pumpkin flowers. This research determines the feasibility of using Puerto Rican cultivars of tropical pumpkin originally developed for fruit production to produce fresh, packaged, and canned edible flowers.

\section{Materials and methods}

Flower Production. Seed of 'Taina Dorada', 'Verde Luz', and experimental line E1101-1 tropical pumpkin, all from the UPRM-AES plant breeding program, and 'Early White Bush Scallop' and 'Early Prolific Straightneck' summer squash (open-pollinated seed produced in isolation at UPRM) were sown in plastic 72-cell trays using a growing mix consisting of $1: 1: 1$ parts by volume of screened composted cow manure, peatmoss, and perlite. Plants were transplanted as 10-d-old seedlings in a randomized complete block design with two replications in a certified organic area of the Lajas Substation of UPRM. The summer squash cultivars were used as controls because, traditionally, edible squash/pumpkin flowers have come from this species. Replicates (plots) consisted of four plants in a single row with plants spaced $6 \mathrm{ft}$ apart within and between rows. Rows were on 6-inch-high $\times 30$ inch-wide raised beds with drip irrigation covered with straw mulch. Irrigation was done as needed based on visual observation. Soils in the experimental area had been previously amended multiple times with organic fertilizers and compost. No additional fertilizer was added. Presence of melonworm (Diaphania hyalinata) was monitored and controlled with Bacillus thuringensis ssp. kurstaki when necessary. At $27 \mathrm{~d}$ (usually every other day) during May and June 2015, male flowers at anthesis (open flower) were harvested from all plants in a plot beginning $\approx 0700 \mathrm{HR}$ each morning. Squash and pumpkin flowers open only a few hours on a single day and then close permanently. Harvesting took $\approx 1 \mathrm{~h}$. The first harvest date corresponded to 29 d after transplanting (DAT). The final harvest occurred at 78 DAT. Fruit were allowed to set on plants. Flowers were cut using scissors, leaving 5 to $8 \mathrm{~cm}$ of stem. At each harvest, the number of flowers/plot was recorded. Harvested flowers were transported in a cooler with ice packs (kept away from the flowers) to the Pilot Plant of the Food Science and Technology Program at UPRM. At the Pilot Plant, stems were cut leaving $1 \mathrm{~cm}$ of stem, flowers were individually weighed 
on an analytical balance [0.01 g (PCl6; Mettler Instrument Corp., Hightstown, $\mathrm{NJ}$ )], and flower length was measured using a ruler.

SHELF LIFE. Four shelf-life experiments (Expts. 1, 2, 3, and 4) were conducted. 'Taína Dorada' and 'Verde Luz' tropical pumpkin and 'Early White Bush Scallop' summer squash were used in all shelf life experiments. In Expt. 1, an additional summer squash cultivar, Early Prolific Straightneck, was included. In Expts. 2 and 4 , 'Soler' tropical pumpkin was also included.

For all shelf-life experiments, male flowers were harvested as needed from plantings in Lajas or Mayagüez, Puerto Rico, during the period from May 2015 to Dec. 2016 (multiple plantings, including the production field described earlier). In Lajas, cultural practices were as described earlier. In Mayagüez, plantings were direct seeded. Water was delivered by drip irrigation as needed based on visual observation. There were no raised beds, and landscape cloth was used for weed control. Four ounces of inorganic granular fertilizer $(10 \mathrm{~N}-$ $4.4 \mathrm{P}-8.3 \mathrm{~K}$ ) was manually applied around the base of each plant at 14 $\mathrm{d}$ after seeding. Melonworm was controlled as in Lajas. Within an experiment, newly opened male flowers for each cultivar $\times$ storage treatment combination were harvested on three sampling dates. Flowers were harvested and transported as described earlier. Once in the laboratory, stamens were removed (a typical practice), and petals were cleaned with a damp towel using potable water. For stored flower treatments, three to four flowers were placed in black polypropylene trays $(137 \times 178 \times$ $35 \mathrm{~mm}$ ) on dry water-absorbent pads, then sealed with plastic [2.4 mil multilayered polyethylene terephthalate-polyethylene (PET/PE) film, supplier not known] using a packaging machine (EP 8488; KOCH Ultra Source, Kansas City, MO). Depending on the shelf-life experiment, samples were stored under passive and/or active MAP conditions, then placed in a refrigerator (Fogel Caribbean Corp., Aguadilla, PR) at 5 and/or $10^{\circ} \mathrm{C}$ [based on studies by Villalta et al. (2004) and López Pérez (2007)] set at $77 \% \pm 2 \%$ relative humidity. For active MAP, the packaging machine was set to inject $5 \% \mathrm{O}_{2}, 11 \%$ $\mathrm{CO}_{2}$, and $84 \% \mathrm{~N}_{2}$, as suggested by Asiain-Morales et al. (2008). Actual
$\mathrm{O}_{2}$ and $\mathrm{CO}_{2}$ values were slightly higher $(6 \%$ to $7 \%$ and $12 \%$ to $13 \%$, respectively) when measured immediately after sealing. For passive MAP, packages were sealed without further intervention.

In shelf life Expt. 1, flower color was evaluated at day 0 (fresh flowers, no packaging) and after $7 \mathrm{~d}$ at $10^{\circ} \mathrm{C}$ with active MAP. At day 7 , flowers were removed from their packaging before measurements were taken. The $\mathrm{a}^{*}$ and $\mathrm{b}^{*}$ values of the tridimensional color space were measured using a spectrophotometer (ColorFlex EZ; Hunter Associates Laboratory, Reston, VA). An average of three readings was used to calculate hue angle and chroma using formulas from McGuire (1992). Measurements were taken on the outside of the upper part of the corolla (Fig. 1).

In shelf life Expt. 2, flowers were subjected to passive and active MAP and stored at 5 and $10^{\circ} \mathrm{C}$, as described earlier. Carbon dioxide and $\mathrm{O}_{2}$ were measured inside packages at days 0 and 5 using a MAP gas analyzer (Servoflex MiniFoodPack 5200; Servomex Co., Brighton, UK).

In shelf life Expt. 3, weight loss (as a percentage of initial weight) was measured in flowers under passive and
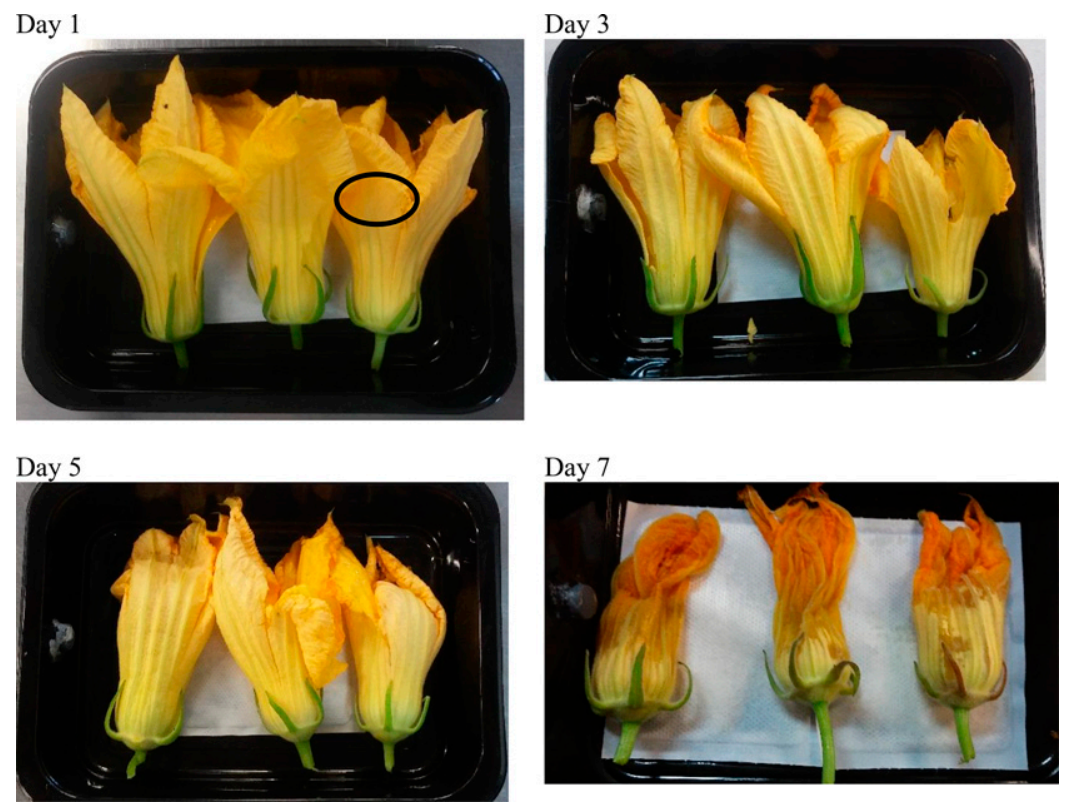

Fig. 1. Examples of male flowers of tropical pumpkin 'Taína Dorada' at days $1,3,5$, and 7 of storage at $5{ }^{\circ} \mathrm{C}\left(41.0{ }^{\circ} \mathrm{F}\right)$ with passive modified atmosphere packaging (MAP). Trays were sealed with plastic film during storage. In shelf-life Expt. 1, color of fresh flowers and flowers stored for $7 \mathrm{~d}$ was measured on the outside of the upper part of the corolla in the area circled in black. Appearance was rated as $5=$ no defects, $4=$ petal slightly curled, $3=$ petals moderately curled, $2=$ petals severely curled, and 1 = flowers wilted and rotting. Flowers in photographs have appearance ratings of 5.0, 3.5, 2.5, and 1.0 for days $1,3,5$, and 7 , respectively. 
active MAP stored at 5 and $10^{\circ} \mathrm{C}$. Weight loss was measured after 3 and 5 d of storage.

In shelf life Expt. 4, flower appearance was evaluated at the end of each of six passive or active MAP storage periods $(2,3,4,5,6$, and $7 \mathrm{~d})$ using a five-point scale where $5=$ no defects, 4 = petals slightly curled, $3=$ petals moderately curled, 2 = petals severely curled, and 1 = flowers wilted and rotting. Flowers with a rating of $\leq 2$ were considered unmarketable. For each storage period $\times$ temperature $\times$ cultivar combination, the number of packages evaluated varied from four to 10 , depending on the availability of flowers of each cultivar.

Chemical AND NUTRITIONAL ANALYSES. Three cultivars of tropical pumpkin (Taina Dorada, Verde Luz, and Soler) and one cultivar of summer squash (Early White Bush Scallop) were evaluated. For chemical analyses, flowers were harvested from plots in Lajas or Mayagüez (cultural practices described earlier) on three separate dates during a period from May 2015 through Dec. 2016, then cleaned and packaged (passive and active MAP) as described earlier. In preparation for measuring soluble solids, titratable acidity, ascorbic acid, antioxidant capacity, total phenolic content, $\mathrm{pH}$, and beta-carotene, flowers were homogenized in a blender (Waring Commercial, Torrington, CT). Readings were taken in triplicate at days 0 and 5 , then averaged. Percentage soluble solids was measured by placing a drop of sample in a digital refractometer (PAL-1; Atago, Toyko, Japan). Titratable acidity was measured using $4 \mathrm{~g}$ of sample added to $36 \mathrm{~mL}$ of distilled water and filtered at vacuum with Whatman paper No. 1, plus three drops of $1 \%$ phenolphthalein alcohol as an indicator. Titration was carried out with $0.1 \mathrm{~N}$ sodium hydroxide until a $\mathrm{pH}$ of 8.20 was reached. Values were expressed as percentages of citric acid [grams citric acid per $100 \mathrm{~g}$ fresh weight (FW)]. For ascorbic acid (vitamin $\mathrm{C}$ ), the Association of Official Analytical Chemists (2003) method 967.21 was followed where $2 \mathrm{~g}$ of flower were extracted with $5 \mathrm{~mL}$ metaphosphoricacetic acid $\left(\mathrm{HPO}_{3}-\mathrm{CH}_{3} \mathrm{COOH}\right)(15 \mathrm{~g}$ $\mathrm{HPO}_{3}$ pellets in $40 \mathrm{~mL} \mathrm{CH}$ COOH and $200 \mathrm{~mL}$ water, diluted to 500 $\mathrm{mL})$, homogenized, and filtered with
Whatman paper No. 4. The filtrate was taken to a volume of $25 \mathrm{~mL}$ in a volumetric flask with deionized water. Afterward, $5 \mathrm{~mL}$ of metaphosphoricacetic acid and $2 \mathrm{~mL}$ of flower extract was titrated with a dye (2,6-dichoroindophenol) previously standardized using L-ascorbic acid. Ascorbic acid was expressed as milligrams ascorbic acid per $100 \mathrm{~g}$ FW. Antioxidant capacity was measured using a 2,2-diphenyll-picrylhydrazyl (DPPH) assay following the procedure of Brand-Williams et al. (1995). The sample was prepared by adding $1 \mathrm{~g}$ homogenized flower in $10 \mathrm{~mL}$ of $80 \%$ ethanol. A $100-\mu \mathrm{L}$ ethanol extract was mixed with $3900 \mu \mathrm{L}$ DPPH reagent $(3.9 \mathrm{mg} / 100 \mathrm{~mL}$ methanol), placed in a $4-\mathrm{mL}$ plastic cuvette and incubated (in the dark) at room temperature for $30 \mathrm{~min}$ to measure decrease in absorbance. Absorbance was read at $517 \mathrm{~nm}$ and values were expressed as micromoles of Trolox equivalents (TE) per gram FW. Total phenolic content was determined by the Folin-Ciocalteau colorimetric method. A total of $20 \mu \mathrm{L}$ of homogenized sample was placed into a $2-\mathrm{mL}$ glass cuvette with $1.58 \mathrm{~mL}$ of water, followed by $100 \mu \mathrm{L}$ of FolinCiocalteau reagent. The sample was mixed thoroughly by inverting and incubated for 1 to $8 \mathrm{~min}$. Then, 300 $\mu \mathrm{L}$ of sodium carbonate were added, and the solution was again mixed and incubated $2 \mathrm{~h}$ at room temperature. Samples were measured at an absorbance of $765 \mathrm{~nm}$ and expressed as milligrams gallic acid equivalents (GAE) per $100 \mathrm{~g} \mathrm{FW.} \mathrm{Measurements}$ of $\mathrm{pH}$ were made using a potentiometer (SympHony SB70P; VWR, Radnor, PA) and a calibrated electrode (ARl5; Fisher Scientific, Hampton, $\mathrm{NH}$ ). Total beta-carotene was determined following the method established by Nagata and Yamashita (1992). One gram of flowers was homogenized in $20 \mathrm{~mL}$ of acetonehexane (4:6) using a stand dispersion unit (Polytron PT 2500 E; Kinematica, Bohemia, NY) for $2 \mathrm{~min}$ at 18,000 rpm. Readings at $663,645,505$, and $453 \mathrm{~nm}$ using an ultraviolet spectrophotometer (ultraviolet-3100PC, VWR) were used in the calculation of total beta-carotene which was expressed as milligrams per $100 \mathrm{~g}$ FW.

Compositional analysis for percentage moisture, ash, fat, and protein and determination of micronutrients were carried out on fresh flowers following methods of the Association of Official Analytical Chemists (2003) or American Oil Chemists' Society (2009). Flowers were collected in Jan. to May 2017 in Mayagüez, PR (cultural practices described above). Percentage carbohydrates was calculated as the difference between $100 \%$ and the sum of percentage moisture, ash, protein, and fat. For each cultivar, phosphorous, potassium, calcium, magnesium, iron, manganese, and zinc were determined in previously digested ash samples of pumpkin flowers following the method established by PerkinElmer Corp. (1996). The digestion process was carried out using $20 \mathrm{~mL}$ of $33 \%$ hydrogen chloride on a hot plate until half of the sample's content was reduced $(\approx 10 \mathrm{~mL})$. After digestion, the samples were filtered using Whatman paper No. 541 in $100-\mathrm{mL}$ volumetric flasks. Washes with demineralized water were carried out until completing volume in the volumetric flask. Mineral contents were determined by an inductively coupled plasma optimal emission spectrometer (Optima 7300 DV; PerkinElmer, Waltham, MA). Concentrations were determined using a standard curve with the elements to be quantified. The average contents of mineral elements were expressed as milligrams per $100 \mathrm{~g} \mathrm{FW}$.

Sensory evaluation. Separate sensory panels were conducted for canned and fresh flowers using a bulk of flowers from 'Soler', 'Verde Luz', and 'Taína Dorada' tropical pumpkin harvested in Lajas and Mayagüez in plots as described earlier. Flowers for canning were collected on a single occasion. For the fresh flower sensory panel, flowers were collected on each of the three mornings the panel was conducted. Flowers were harvested and transported as described earlier. Stamens were removed and petals were cleaned with a damp towel using potable water. For canning, flowers were disinfected with chlorine (200 ppm in $1 \mathrm{~L}$ of water) for $1 \mathrm{~min}$, rewashed with water, and blanched for $1 \mathrm{~min}$ and $50 \mathrm{~s}$ at $100^{\circ} \mathrm{C}$. Immediately following blanching, flowers were submerged in a water bath with ice for $2 \mathrm{~min}$ then drained to remove excess water and placed into a glass jar containing a hot $1.8 \%$ saline solution. Using $1 \%$ citric acid, the $\mathrm{pH}$ of the 
Table 1. Mean number of male flowers/day per plant and mean weight and length of flowers over a 27-d harvest period in May and June 2015 in Lajas, PR of 'Taína Dorada', 'Verde Luz', and E1101 tropical pumpkin and 'Early White Bush Scallop' and 'Early Prolific Straighneck' summer squash.

\begin{tabular}{lccc}
\hline Cultivar & Male flowers $($ no./plant/d) & Flower wt $(\mathbf{g})^{\mathbf{z}}$ & ${\text { Flower length }(\mathbf{c m})^{\mathbf{z}}}^{\text {Taína Dorada }}$ \\
Verde Luz & $3.38 \mathrm{ab}^{\mathrm{y}}$ & $8.05 \mathrm{ab}$ & $11.33 \mathrm{~b}$ \\
E1101 & $3.42 \mathrm{~b}$ & $8.80 \mathrm{a}$ & $12.47 \mathrm{a}$ \\
Early White Bush Scallop & $2.94 \mathrm{~b}$ & $7.87 \mathrm{~b}$ & $12.71 \mathrm{a}$ \\
Early Prolific Straightneck & $4.03 \mathrm{a}$ & $2.93 \mathrm{c}$ & $8.54 \mathrm{c}$ \\
Tukey LSD $(0.05)^{\mathrm{x}}$ & $1.78 \mathrm{c}$ & $3.29 \mathrm{c}$ & $8.47 \mathrm{c}$ \\
\hline
\end{tabular}

${ }^{\mathrm{z}} \mathrm{l} \mathrm{g}=0.0353 \mathrm{oz} ; \mathrm{l} \mathrm{cm}=0.3937$ inch.

${ }^{y}$ Within a column, means followed by a common letter are not different $(P>0.05)$ according to Tukey's test.

${ }^{\mathrm{x}}$ Tukey's least significant difference $(P=0.05)$ for comparisons between cultivar means.

solution was measured and adjusted to 4.6. Jars were sealed by placing them in a water bath at $82^{\circ} \mathrm{C}$ for 5 min then letting them cool at room temperature (Codex Alimentarius, 2011). The canned flowers were stored at room temperature until the sensory evaluation took place $\approx 1$ month later. A minimum of 100 panelists was used for each sensory panel (canned and fresh flowers), and the participants were of both sexes, of various ages, and included both students and employees of UPRM. For each sensory panel, evaluations took place on three dates and results were combined over dates. All sensory analyses took place on the UPRM campus. Participants varied at each date. Participants were prescreened, and only those who indicated that they liked vegetables such as lettuce were asked to participate. Texture, taste, and general acceptance were evaluated on fresh flowers. Canned flowers were evaluated only on general acceptance. In both cases, a nine-point hedonic scale was used where $9=$ like extremely, 5 = neither like nor dislike, and $\mathrm{l}=$ dislike extremely $(\mathrm{Lim}$, 2011). Panelists were given one to two blossoms when evaluating freshly harvested pumpkin flowers and one cooked flower when evaluating canned flowers. For fresh flowers, 103 panelists evaluated texture, 112 evaluated taste, and 118 evaluated overall acceptability; 127 panelists evaluated general acceptability of canned flowers. Panelists were also surveyed on their willingness to purchase pumpkin flowers.

Data analysis. All statistical analyses were carried out using InfoStat software (version 2019; Di Rienzo et al., 2019). The flower production experiment was analyzed as a randomized complete block design with two replications and five cultivars. Shelf-life experiments and chemical evaluations were initially analyzed as randomized complete block designs with three replications, except for shelf-life Expt. 4 (appearance) where number of replications varied from four to 10 . Because block effects were generally not significant, they were pooled with the error term. When applicable, a factorial analysis (cultivars $\times$ storage treatments) was conducted. $F$-tests were used to test the significance of interaction and main effects. Means were separated using Tukey's least significant difference comparison test or compared using single-degreeof-freedom linear contrasts.

\section{Results}

FlOWER PRODUCTION. 'Early White Bush Scallop' and 'Early Prolific Straightneck' summer squash produced the first male flowers beginning at 29 DAT (data not shown). 'Taina Dorada' and E1101-1 tropical pumpkin began to produce flowers at 44 DAT, followed by 'Verde Luz' tropical pumpkin flowering at 51 DAT. Average flower production ranged from 1.78 to 4.03 flowers/plant/day (Table 1). Flower production in summer squash greatly declined beginning about 60 DAT while production in tropical pumpkin remained strong through the end of the experiment. 'Early Prolific Straightneck' summer squash produced the lowest number of flowers per plant per day while the other summer squash cultivar, along with two of the tropical pumpkin cultivars, produced the largest number of flowers per day. Average flower weight among the three tropical pumpkin cultivars was more than twice that of the two summer squash cultivars. The flowers of tropical pumpkin were up to
$50 \%$ longer than those of summer squash.

Shelf-life Expt. 1: Flower COLOR. Hue angle and chroma decreased between day 0 (fresh flowers) and day 7 across all cultivars (Table 2). Since a hue angle of $90^{\circ}$ corresponds to a yellow color while a hue angle of $45^{\circ}$ corresponds to orange, flowers became more orange as they aged. The decrease in chroma indicated less color saturation with increased flower age. Fresh flowers of tropical pumpkin cultivars tended to have slightly higher hue angle values (more yellow than orange in color) than did flowers of the summer squash cultivars, although the difference was small and not always significant. After $7 \mathrm{~d}$ of storage, the trend was reversed, with tropical pumpkin cultivars tending toward a more orange color compared with summer squash cultivars. Tropical pumpkin cultivars stored for $7 \mathrm{~d}$ tended to have lower chroma values (less color saturation) than summer squash cultivars, although the differences were not always significant. No similar trend was observed for chroma of fresh flowers.

Shelf life Expt. 2: Changes IN $\mathrm{O}_{2}$ AND $\mathrm{CO}_{2}$. There was a strong decrease in the level of $\mathrm{O}_{2}$ and increase in level of $\mathrm{CO}_{2}$ between day 0 (fresh flowers) and day 5 when flowers were packaged with passive MAP (Fig. 2). On average (over all cultivars and storage temperatures), the percentage $\mathrm{O}_{2}$ in packages with passive MAP decreased from $20.9 \%$ on day 0 to $6.6 \%$ on day 5 , whereas $\mathrm{CO}_{2}$ increased from $0.8 \%$ on day 0 to $17.5 \%$ on day 5 . With active MAP, as with passive MAP, $\mathrm{O}_{2}$ levels decreased and $\mathrm{CO}_{2}$ levels increased between days 0 and 5 , but these changes were much smaller, and often not significant, compared 
Table 2. Shelf-life Expt. 1: Mean hue angle and chroma of male flowers of 'Taína Dorada' and 'Verde Luz' tropical pumpkin and 'Early White Bush Scallop' and 'Early Prolific Straightneck' summer squash on day 0 (fresh) and after $7 \mathrm{~d}$ of storage at $10^{\circ} \mathrm{C}\left(50.0{ }^{\circ} \mathrm{F}\right)$ under active modified atmosphere packaging where packages were initially injected with $6 \%$ to $7 \%$ oxygen and $12 \%$ to $13 \%$ carbon dioxide (nitrogen used to complete volume to $100 \%$ ).

\begin{tabular}{lccccc}
\hline & \multicolumn{2}{c}{ Hue angle $\left(^{\circ}\right)$} & & \multicolumn{2}{c}{ Chroma } \\
\cline { 2 - 3 } Cultivar & Fresh $^{\mathrm{z}}$ & Day 7 & & Fresh & Day 7 \\
\hline Taína Dorada & $71.53 \mathrm{a}^{\mathrm{y}}$ & $50.90 \mathrm{~b}$ & & $70.34 \mathrm{bc}$ & $34.34 \mathrm{~b}$ \\
Verde Luz & $72.56 \mathrm{a}$ & $50.71 \mathrm{~b}$ & & $76.29 \mathrm{a}$ & $37.16 \mathrm{~b}$ \\
Early White Bush Scallop & $70.69 \mathrm{ab}$ & $55.88 \mathrm{ab}$ & & $65.29 \mathrm{c}$ & $43.18 \mathrm{~b}$ \\
Early Prolific Straightneck & $69.04 \mathrm{~b}$ & $59.50 \mathrm{a}$ & & $71.68 \mathrm{ab}$ & $54.20 \mathrm{a}$ \\
Tukey LSD $(0.05)^{\mathrm{x}}$ & 2.27 & 6.33 & & 5.47 & 9.64 \\
\hline
\end{tabular}

${ }^{\mathrm{z} W i t h i n ~ a ~ c u l t i v a r ~(r o w), ~ m e a n s ~ o f ~ f r e s h ~ f l o w e r s ~ v s . ~ f l o w e r s ~ a t ~ d a y ~} 7$ were always different $(P \leq 0.05)$ according to the Tukey's test. Values of Tukey's least significant difference $(P=0.05)$ for the comparison of fresh flowers vs. flowers at day 7 are 4.188 and 8.155 , for hue angle and chroma, respectively.

'Within a column, means followed by a common letter are not different $(P>0.05)$ according to Tukey's test.

${ }^{x}$ Tukey's least significant difference $(P=0.05)$ for comparisons between cultivar means.

with the much larger changes observed with passive MAP. For flowers stored with passive or active MAP, the magnitude of these changes varied, depending on the cultivar and storage temperature (significant interaction, $P$ ranging from
$<0.0001$ to 0.0353$)$. However, within a particular combination of temperature and type of MAP, the general pattern was the same for all cultivars. Storage temperature generally had little effect on the magnitude of the decrease in $\mathrm{O}_{2}$ or the increase in $\mathrm{CO}_{2}$ during the $5 \mathrm{~d}$ of storage.

Shelf LIFE EXPT. 3: Weight Loss. Percentage weight loss (compared with fresh flowers at day 0) averaged $10.7 \% \quad\left(5^{\circ} \mathrm{C}\right)$ and $13.5 \%$ $\left(10^{\circ} \mathrm{C}\right)$ at day 3 , then significantly increased to $27.1 \%\left(5^{\circ} \mathrm{C}\right)$ and $26.9 \%$ $\left(10^{\circ} \mathrm{C}\right.$ ) at day $5($ Table 3$)$. There was a tendency (not always significant) for greater weight loss in flowers of 'Early White Bush Scallop' summer squash compared with the tropical pumpkin cultivars. The use of passive vs. active MAP had no effect on weight loss in stored flowers.

Shelf life Expt. 4: Flower QUALITY (APPEARANCE). Linear contrasts demonstrated that the type of packaging (passive vs. active MAP) had an inconsistent effect on flower appearance scores (Table 4). From days 2 to 5 , the use of active MAP generally resulted in better flower appearance in 'Early White Bush Scallop' summer
Flowers stored at $5^{\circ} \mathrm{C}$
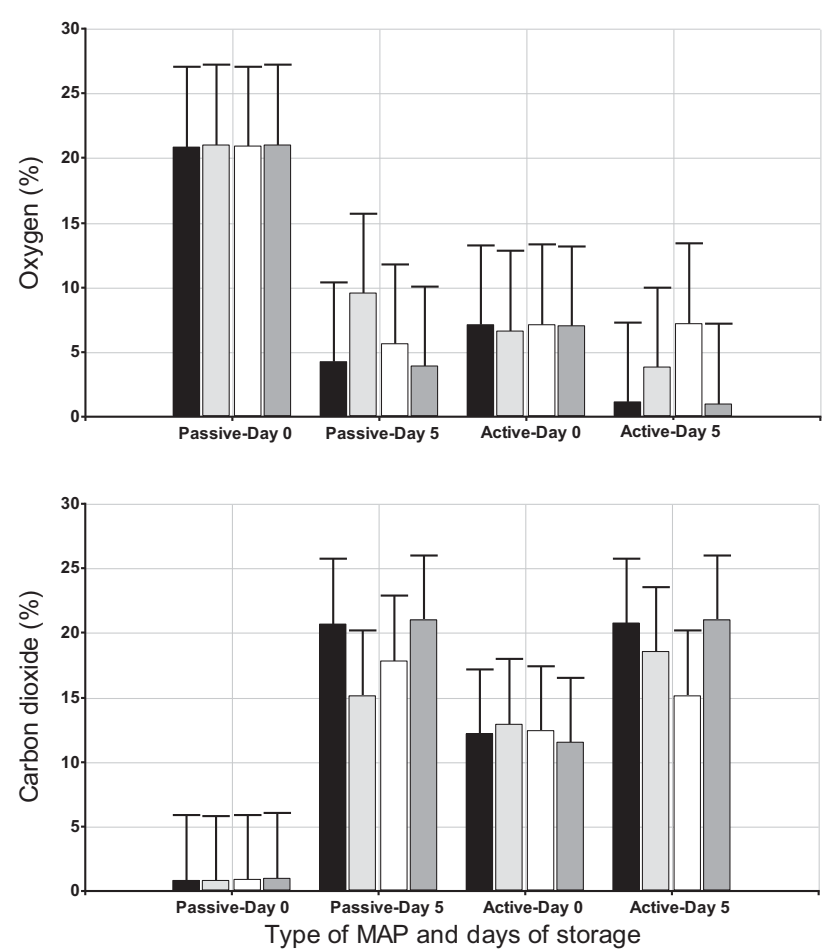

Soler

Verde Luz
Flowers stored at $10{ }^{\circ} \mathrm{C}$
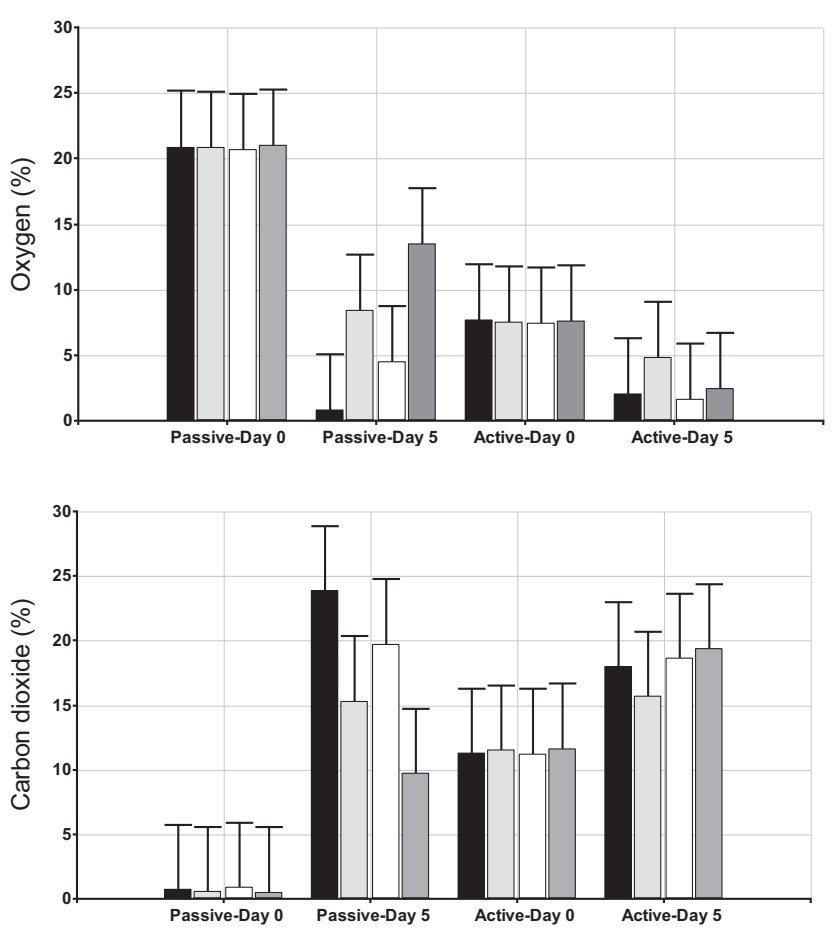

Type of MAP and days of storage

Taina Dorada

Early White Bush Scallop

Fig. 2. Shelf-life Expt. 2: percentage oxygen and carbon dioxide in packages of male flowers of 'Soler', 'Taína Dorada', and 'Verde Luz' tropical pumpkin, and 'Early White Bush Scallop' summer squash sealed with plastic film, and stored at 5 and $10^{\circ} \mathrm{C}\left(41.0\right.$ and $\left.50.0^{\circ} \mathrm{F}\right)$ under passive and active modified atmosphere packaging (MAP). Packages with active MAP were initially injected with $6 \%$ to $7 \%$ oxygen and $12 \%$ to $13 \%$ carbon dioxide (nitrogen used to complete volume to $100 \%$ ). Vertical bars correspond to Tukey's least significant difference at the $0.05 P$ level. 
Table 3. Shelf-life Expt. 3: Mean percentage weight loss at 3 and $5 \mathrm{~d}$ postharvest compared with day 0 (fresh flowers) in male flowers of 'Taína Dorada' and 'Verde Luz' tropical pumpkin and 'Early White Bush Scallop' summer squash subjected to passive or active modified atmosphere packaging (MAP) and stored at 5 and $10^{\circ} \mathrm{C}\left(41.0\right.$ and $\left.50.0{ }^{\circ} \mathrm{F}\right)$. Packages with active MAP were initially injected with $6 \%$ to $7 \%$ oxygen and $12 \%$ to $13 \%$ carbon dioxide (nitrogen used to complete volume to $100 \%$ ).

\begin{tabular}{|c|c|c|c|c|}
\hline \multirow[b]{3}{*}{ Effect } & \multicolumn{4}{|c|}{ Wt loss $(\%)^{\mathrm{z}}$} \\
\hline & \multicolumn{2}{|c|}{ Stored at $5^{\circ} \mathrm{C}$} & \multicolumn{2}{|c|}{ Stored at $10^{\circ} \mathrm{C}$} \\
\hline & Day 3 & Day 5 & Day 3 & Day 5 \\
\hline \multicolumn{5}{|l|}{ Cultivar } \\
\hline Taína Dorada & $9.82 b^{y}$ & $20.69 \mathrm{~b}$ & $14.96 \mathrm{ab}$ & $23.77 b$ \\
\hline Verde Luz & $7.41 \mathrm{~b}$ & $29.29 \mathrm{a}$ & $7.74 \mathrm{~b}$ & $19.57 \mathrm{~b}$ \\
\hline \multicolumn{5}{|l|}{ Type of packaging } \\
\hline Passive MAP & $10.80 \mathrm{a}$ & $26.38 \mathrm{a}$ & $14.65 \mathrm{a}$ & $28.69 \mathrm{a}$ \\
\hline Active MAP & $10.55 \mathrm{a}$ & $25.79 \mathrm{a}$ & $12.31 \mathrm{a}$ & $24.22 \mathrm{a}$ \\
\hline Tukey LSD $(0.05)^{\mathrm{x}}$ & \multicolumn{2}{|c|}{1.661} & \multicolumn{2}{|c|}{4.864} \\
\hline \multicolumn{5}{|l|}{$\mathrm{C} \times \mathrm{P}$} \\
\hline$F$ test probability & \multicolumn{2}{|c|}{0.6154} & \multicolumn{2}{|c|}{0.9192} \\
\hline
\end{tabular}

squash. In contrast, flowers of tropical pumpkin tended to fare better under passive MAP, especially from days 4 to 6 of storage. The effect of storage temperature was stronger than the effect of type of MAP. When there was a significant temperature effect (in approximately half of the linear contrasts), flowers stored at $5^{\circ} \mathrm{C}$ had a better appearance score than flowers stored at $10^{\circ} \mathrm{C}$. This effect was especially consistent in 'Taína Dorada' tropical pumpkin. Figure 1 shows the general appearance of 'Taína Dorada' tropical pumpkin stored at $5^{\circ} \mathrm{C}$ under passive MAP over a 7 -d storage period. Loss of quality (lower appearance score) over time was slower in flowers of tropical pumpkin cultivars compared with that of the summer squash cultivar. At day 4 , the appearance rating of 'Soler', 'Taina Dorada', and 'Verde Luz' tropical pumpkin averaged 3.6 (petals slightly to moderately curled) compared with 2.1 (petals severely curled) for 'Early White Bush Scallop' summer squash. At day 5 the tropical pumpkin cultivars averaged 2.6 (petals moderately to severely curled) compared with 1.8 (petals severely curled or decaying) for 'Early White Bush Scallop' summer squash. At days 6 and 7 the appearance of flowers of all combinations of type of MAP, storage temperature and cultivar was rated $\leq 2$ (with one exception of 2.5) making them unmarketable. Linear contrasts indicated that flowers of 'Soler' tropical pumpkin maintained the best appearance over time, followed by "Verde Luz' tropical pumpkin.

Chemical AND NUTRITIONAL PROPERTIES. Compared with fresh flowers, soluble solids, total acidity, ascorbic acid, antioxidant activity, and total phenolics decreased in flowers stored for $5 \mathrm{~d}$ (Fig. 3). This was true for each cultivar, storage temperature, and type of packaging (passive or active MAP). The decrease in concentration of soluble solids after $5 \mathrm{~d}$ was greater in 'Verde Luz' tropical pumpkin compared with the other cultivars [significant cultivar $\times$ storage treatment interaction $(P<0.001)]$. Flowers stored for $5 \mathrm{~d}$ exhibited at least a $75 \%$ decrease in total acidity and at least a $50 \%$ reduction in ascorbic acid in every cultivar. The magnitude of reduction in antioxidant capacity in stored flowers varied greatly, depending on cultivar and storage treatment [significant cultivar $\times$ storage treatment interaction $(P<0.001)]$, but the reduction was always at least $30 \%$. Compared with fresh flowers, total phenolics content decreased in stored flowers by more than $50 \%$. The $\mathrm{pH}$ of flowers increased with storage. This increase was considerably greater and more consistent in 'Taína Dorada' tropical pumpkin and 'Early White Bush Scallop' summer squash than in 'Soler' and 'Verde Luz' tropical pumpkin [significant cultivar $\times$ storage treatment interaction $(P<$ $0.001)]$. Despite significant differences, the actual range of differences in $\mathrm{pH}$ values (6.7 to 7.5 ) was not great in fresh vs. stored flowers. The response of beta-carotene was inconsistent, varying by cultivar [significant cultivar $\times$ storage treatment interaction $(P=0.019)]$.

Storage temperature had little or no effect on soluble solids, acidity, ascorbic acid, and beta-carotene in stored flowers (Fig. 3). There were inconsistent effects of temperature on $\mathrm{pH}$ and antioxidant capacity. In some cultivars $\mathrm{pH}$ increased in flowers stored at $10{ }^{\circ} \mathrm{C}$ compared with $5^{\circ} \mathrm{C}$, whereas in other cultivars $\mathrm{pH}$ decreased at $10^{\circ} \mathrm{C}$ or did not change at all. Antioxidant capacity was higher in flowers stored at $5^{\circ} \mathrm{C}$ than at $10^{\circ} \mathrm{C}$, except in the case of 'Taína Dorada' tropical pumpkin where it was higher in flowers stored at $10^{\circ} \mathrm{C}$. For all cultivars, total phenolics was higher at $5^{\circ} \mathrm{C}$ under passive MAP, but total phenolics was unaffected by storage temperature when flowers were stored under active MAP.

Across all cultivars and storage temperatures, ascorbic acid did not vary among types of MAP after $5 \mathrm{~d}$ of storage (Fig. 3). Acidity and betacarotene did not change in flowers stored with passive vs. active MAP with two exceptions: in 'Early White 
Table 4. Shelf-life Expt. 4: Mean appearance of male flowers of 'Soler', 'Taína Dorada', and 'Verde Luz' tropical pumpkin and 'Early White Bush Scallop' (Bush Scallop) summer squash stored over $7 \mathrm{~d}$ at 5 and $10^{\circ} \mathrm{C}\left(41.0\right.$ and $\left.50.0{ }^{\circ} \mathrm{F}\right)$ under passive or active modified atmosphere packaging (MAP). Packages with active MAP were initially injected with $6 \%$ to $7 \%$ oxygen and $12 \%$ to $13 \%$ carbon dioxide (nitrogen used to complete volume to $100 \%$ ). The single-degree-of-freedom linear contrasts compare type of MAP, storage temperatures, and cultivars.

Mean appearance of male flowers $(1-5 \text { scale })^{\mathrm{z}}$

\begin{tabular}{|c|c|c|c|c|c|c|c|c|}
\hline $\begin{array}{l}\text { Type of } \\
\text { MAP }\end{array}$ & $\begin{array}{c}\text { Temp } \\
\left({ }^{\circ} \mathbf{C}\right)\end{array}$ & Cultivar & Day 2 & Day 3 & Day 4 & Day 5 & Day 6 & Day 7 \\
\hline Passive & 10 & Soler & $5.0 \mathrm{a}^{\mathrm{y}}$ & $5.0 \mathrm{a}$ & $5.0 \mathrm{a}$ & $3.0 \mathrm{~b}$ & $1.0 \mathrm{a}$ & $1.0 \mathrm{a}$ \\
\hline Active & 10 & Soler & $5.0 \mathrm{a}$ & $5.0 \mathrm{a}$ & $4.0 \mathrm{bc}$ & $1.7 \mathrm{ef}$ & $1.0 \mathrm{c}$ & $1.0 \mathrm{a}$ \\
\hline Active & 5 & Soler & $5.0 \mathrm{a}$ & $4.8 \mathrm{ab}$ & $4.1 \mathrm{ab}$ & $3.0 \mathrm{~b}$ & $1.0 \mathrm{c}$ & $1.0 \mathrm{a}$ \\
\hline Passive & 10 & TD & $4.0 \mathrm{~b}$ & $3.6 \mathrm{~cd}$ & $2.4 \mathrm{ef}$ & $2.0 \mathrm{de}$ & $1.0 \mathrm{c}$ & $1.0 \mathrm{a}$ \\
\hline Active & 10 & TD & $5.0 \mathrm{a}$ & $3.7 \mathrm{bcd}$ & 3.2 bcde & $2.0 \mathrm{de}$ & $1.0 \mathrm{c}$ & $1.0 \mathrm{a}$ \\
\hline Active & 5 & TD & $5.0 \mathrm{a}$ & $4.1 \mathrm{abc}$ & $3.9 \mathrm{bcd}$ & $2.0 \mathrm{de}$ & $1.0 \mathrm{c}$ & $1.0 \mathrm{a}$ \\
\hline Passive & 10 & VL & $5.0 \mathrm{a}$ & $3.9 \mathrm{abc}$ & $3.9 \mathrm{bcd}$ & $2.5 \mathrm{bcd}$ & $2.5 \mathrm{a}$ & $1.0 \mathrm{a}$ \\
\hline Active & 10 & VL & $5.0 \mathrm{a}$ & $4.0 \mathrm{abc}$ & $3.0 \mathrm{def}$ & $2.5 \mathrm{bcd}$ & $1.0 \mathrm{c}$ & $1.0 \mathrm{a}$ \\
\hline Passive & 5 & VL & $5.0 \mathrm{a}$ & $4.4 \mathrm{abc}$ & 3.1 cdef & $3.1 \mathrm{~b}$ & $1.0 \mathrm{c}$ & $1.0 \mathrm{a}$ \\
\hline Active & 5 & VL & $5.0 \mathrm{a}$ & $4.1 \mathrm{abc}$ & 3.1 bcde & $2.7 \mathrm{bcd}$ & $1.0 \mathrm{c}$ & $1.0 \mathrm{a}$ \\
\hline Passive & 10 & BS & $4.0 \mathrm{~b}$ & $2.8 \mathrm{de}$ & $1.0 \mathrm{~g}$ & $1.0 \mathrm{f}$ & $1.0 \mathrm{c}$ & $1.0 \mathrm{a}$ \\
\hline \multicolumn{9}{|c|}{ Linear contrast $^{\mathrm{w}}$} \\
\hline \multicolumn{2}{|c|}{ Passive vs. active } & Soler & NS $(>0.999)$ & NS $(0.681)$ & Passive $(0.034)$ & Passive $(<0.001)$ & Passive $(<0.001)$ & NS $(>0.999)$ \\
\hline \multicolumn{2}{|c|}{ Passive vs. active } & TD & Active $(<0.001)$ & Ns $(0.323)$ & Active $(<0.001)$ & Passive (0.019) & Passive $(<0.001)$ & Ns $(>0.999)$ \\
\hline \multicolumn{2}{|c|}{ Passive vs. active } & VL & Ns $(>0.999)$ & Ns $(0.792)$ & Passive $(0.028)$ & NS $(0.221)$ & Passive $(<0.001)$ & Ns $(>0.999)$ \\
\hline \multicolumn{2}{|c|}{ Passive vs. active } & BS $\quad A$ & Active $(<0.001)$ & NS $(0.113)$ & Active $(<0.001)$ & Active $(<0.001)$ & NS $(>0.999)$ & Ns $(>0.999)$ \\
\hline \multicolumn{2}{|c|}{5 vs. $10^{\circ} \mathrm{C}$} & Soler & Ns $(>0.999)$ & Ns $(0.681)$ & $10^{\circ} \mathrm{C}(0.034)$ & $5^{\circ} \mathrm{C}(<0.001)$ & $5^{\circ} \mathrm{C}(<0.001)$ & Ns $(>0.999)$ \\
\hline \multicolumn{2}{|c|}{5 vs. $10^{\circ} \mathrm{C}$} & $\mathrm{TD}$ & $5^{\circ} \mathrm{C}(<0.001)$ & $5^{\circ} \mathrm{C}(0.042)$ & $5^{\circ} \mathrm{C}(<0.001)$ & $5^{\circ} \mathrm{C}(0.019)$ & $5^{\circ} \mathrm{C}(<0.001)$ & Ns $(>0.999)$ \\
\hline \multicolumn{2}{|c|}{5 vs. $10^{\circ} \mathrm{C}$} & VL & NS $(>0.999)$ & NS $(0.169)$ & NS $(0.068)$ & $5^{\circ} \mathrm{C}(0.008)$ & $10^{\circ} \mathrm{C}(<0.001)$ & Ns $(>0.999)$ \\
\hline \multicolumn{2}{|c|}{5 vs. $10^{\circ} \mathrm{C}$} & BS & $10^{\circ} \mathrm{C}(<0.001)$ & $5^{\circ} \mathrm{C}(0.037)$ & $5^{\circ} \mathrm{C}(<0.001)$ & NS $(0.050)$ & NS $(>0.999)$ & Ns $(>0.999)$ \\
\hline
\end{tabular}

\footnotetext{
${ }^{\mathrm{z}}$ Appearance rated as $\mathbf{5}=$ no defects, $4=$ petal slightly curled, $3=$ petals moderately curled, $2=$ petals severely curled, and $\mathrm{l}=$ flowers wilted and rotting.

${ }^{y}$ Within a column, means followed by the same letter are not significantly different $(P>0.05)$ according to Tukey's test.

${ }^{x}$ Tukey's least significant difference $(P=0.05)$ for comparisons between means.

${ }^{w}$ For linear contrasts, the treatment group (type of MAP, temperature, cultivar) with a higher mean (= better appearance) is indicated followed by the probability value of the $F$-test in parenthesis. NS $=$ no significant difference.

$\mathrm{BS}=$ Bush Scallop; $\mathrm{TD}=$ Taína Dorada $; \mathrm{VL}=$ Verde Luz
}

Bush Scallop' summer squash acidity was higher for active MAP at $10^{\circ} \mathrm{C}$ and in 'Verde Luz' tropical pumpkin beta-carotene was higher for active MAP at $10^{\circ} \mathrm{C}$. For all other chemical parameters, the effect of passive vs. active MAP, when significant, varied depending on cultivar, on storage temperature or on both effects. For soluble solids concentration at $10^{\circ} \mathrm{C}$, there was no difference between passive and active MAP for any cultivar. In contrast, at $5{ }^{\circ} \mathrm{C}$ under active MAP percent soluble solids increased in 'Soler', decreased in 'Verde Luz' and did not change in 'Taína Dorada'. For $\mathrm{pH}$, flowers under active MAP sometimes exhibited a reduced $\mathrm{pH}$ (for 'Soler' at both temperatures and for 'Verde Luz' at $10^{\circ} \mathrm{C}$ ). Although the magnitude of the change de-pended on the cultivar, active MAP decreased antioxidant capacity in flowers at $5{ }^{\circ} \mathrm{C}$ and increased antioxidant capacity at $10{ }^{\circ} \mathrm{C}$. At $5{ }^{\circ} \mathrm{C}$, there was a reduction in total phenolics in flowers with active MAP, whereas no difference in phenolics was observed in flowers under passive and active MAP at $10{ }^{\circ} \mathrm{C}$.

There were some significant differences between cultivars for percentage ash, fat, and protein but generally these differences were small (Table 5 ). The micronutrients present in pumpkin flowers were phosphorous, potassium, calcium, magnesium, iron, zinc, and manganese. The most prevalent mineral was potassium, ranging from 231.87 to $290.76 \mathrm{mg} / 100 \mathrm{~g} \mathrm{FW}$ among cultivars. 

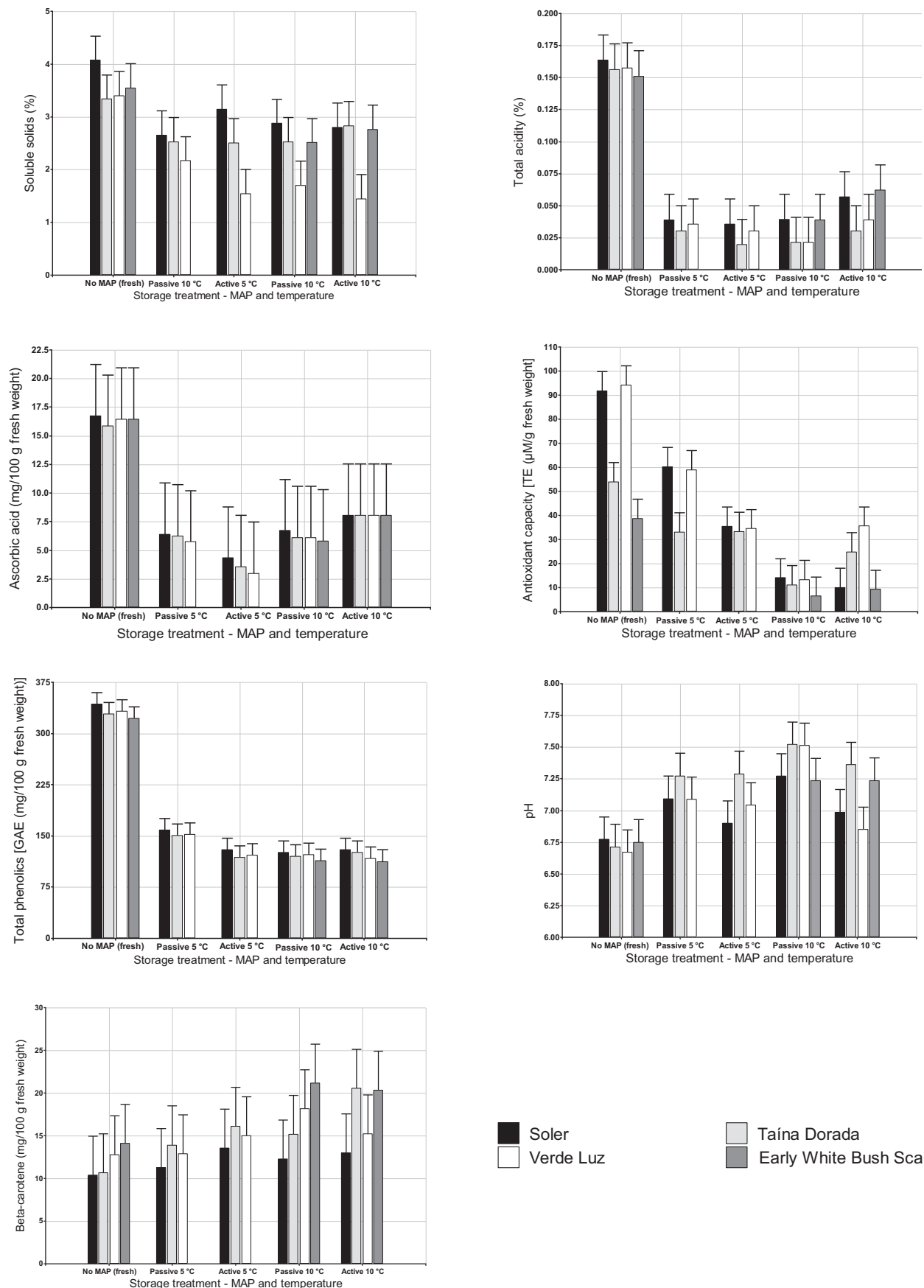

Taína Dorada

Soler

Early White Bush Scallop

Fig. 3. Mean soluble solids, total acidity, ascorbic acid, antioxidant capacity [expressed as Trolox equivalents (TE) in a 2,2diphenyl-1-picrylhydrazyl (DPPH) assay], total phenolics [expressed in gallic acid equivalents (GAE)], pH, and betacarotene in male flowers of 'Soler', 'Taína Dorada', and 'Verde Luz' tropical pumpkin, and 'Early White Bush Scallop' summer squash at day 0 (fresh) and after $5 \mathrm{~d}$ of passive or active modified atmosphere packaging (MAP). Packaged flowers were sealed with plastic film and stored at 5 and $10^{\circ} \mathrm{C}\left(41.0\right.$ and $\left.50.0{ }^{\circ} \mathrm{F}\right)$. Packages with active MAP were initially injected with $6 \%$ to $7 \%$ oxygen and $12 \%$ to $13 \%$ carbon dioxide (nitrogen used to complete volume to $100 \%$ ). Vertical bars represent Tukey's least significant difference at the $5 \%$ probability level for comparison of any two means. 'Early White Bush Scallop' was not tested at $5{ }^{\circ} \mathrm{C} ; 1 \mathrm{mg} / 100 \mathrm{~g}=10 \mathrm{ppm}, 1 \mu \mathrm{M} / \mathrm{g}=28.3495 \mu \mathrm{M} / \mathrm{oz}$.

Sensory eValuations. The mean ratings for fresh flower texture (7.6), taste (7.2), and overall acceptability (7.5) fell between the categories of "like moderately" to "like very much" on the hedonic scale. More than $80 \%$ of panelists had a positive impression of the texture and taste of fresh flowers, scoring these attributes from "like slightly" to "like extremely." Panelists often noted that the texture was like lettuce and made comments such as "excellent flavor," "refreshing," and a "sweet" or "soft" taste. Some panelists commented on the lack of taste or that flowers needed more flavor but at the same time indicated that they would be willing to eat them in salads with dressing. Panelists generally found the color of fresh flowers to be attractive. Seventy 
Table 5. Mean percentage of food components and mineral content of male flowers of 'Soler', 'Taína Dorada', and 'Verde Luz' tropical pumpkin and 'Early White Bush Scallop' summer squash harvested from Jan. to May 2017 in Mayagüez, PR.

\begin{tabular}{|c|c|c|c|c|c|}
\hline & Soler & Taína Dorada & Verde Luz & Early White Bush Scallop & Tukey LSD $(0.05)^{\mathrm{z}}$ \\
\hline Food component or mineral & \multicolumn{5}{|c|}{ Food component (\%) } \\
\hline Moisture & $93.72 \mathrm{a}^{\mathrm{y}}$ & $94.12 \mathrm{a}$ & $94.25 \mathrm{a}$ & $93.79 \mathrm{a}$ & 0.66 \\
\hline Fat & $0.09 \mathrm{~b}$ & $0.15 \mathrm{a}$ & $0.13 \mathrm{a}$ & $0.09 \mathrm{~b}$ & 0.03 \\
\hline Protein & $1.91 \mathrm{a}$ & $1.43 \mathrm{c}$ & $1.37 \mathrm{c}$ & $1.60 \mathrm{~b}$ & 0.15 \\
\hline Carbohydrates $^{\mathrm{x}}$ & 3.50 & 3.60 & 3.52 & 3.82 & - \\
\hline Phosphorus & $33.91 \mathrm{~b}$ & $31.02 \mathrm{~b}$ & $31.26 \mathrm{~b}$ & $39.47 \mathrm{a}$ & 5.19 \\
\hline Potassium & $290.76 \mathrm{a}$ & $231.87 \mathrm{~b}$ & $278.11 \mathrm{a}$ & $278.59 \mathrm{a}$ & 13.76 \\
\hline Calcium & $58.40 \mathrm{a}$ & $52.22 \mathrm{a}$ & $53.80 \mathrm{a}$ & $45.07 \mathrm{a}$ & 23.09 \\
\hline Magnesium & $25.96 \mathrm{a}$ & $23.76 \mathrm{a}$ & $20.50 \mathrm{a}$ & $24.18 \mathrm{a}$ & 5.18 \\
\hline Iron & $2.07 \mathrm{a}$ & $1.06 \mathrm{~b}$ & $1.20 \mathrm{~b}$ & $1.07 \mathrm{~b}$ & 0.33 \\
\hline Manganese & $0.17 \mathrm{~b}$ & $0.21 \mathrm{a}$ & $0.13 \mathrm{c}$ & $0.24 \mathrm{a}$ & 0.03 \\
\hline
\end{tabular}

zTukey's least significance difference $(P=0.05)$ for within-row comparisons between cultivars.

yWithin a row, means with a common letter are not significantly different $(P>0.05)$ according to Tukey's test.

${ }^{x}$ Percentage carbohydrates was determined as the difference between $100 \%$ and the sum of percentages of moisture, ash, protein, and fat.

${ }^{\mathrm{w}} 1 \mathrm{mg} / 100 \mathrm{~g}=10 \mathrm{ppm}$.

percent of panelists indicated that they would be willing to buy locally produced pumpkin flowers, $9 \%$ of panelists would not buy flowers, 10\% were undecided, and 11\% did not answer the question. Canned flowers were evaluated only for overall acceptability. Sixty-two percent of panelists had a positive impression of canned flowers, rating overall acceptability from "like slightly" to "like extremely." Another $26 \%$ of participants were undecided ("neither like nor dislike"). The mean acceptability score was 7.0, corresponding to "like moderately." Many panelists expressed surprise by how much they liked canned pumpkin flowers. They mentioned that they had a good taste and texture and would be an appealing addition to soups and salads. Some panelists who gave lower scores mentioned that canned flowers had little taste and needed more salt.

\section{Discussion}

FlOWER PRODUCTION. In most squash and pumpkin cultivars, male flowers appear several days to weeks before female flowers. Both male and female pumpkin flowers remain open for $1 \mathrm{~d}$, and only in the morning. The number of days from planting to flowering can vary considerably depending on cultivar and environmental effects such as daylength (determined by latitude) and temperature. Long, warm days often result in the production of male flowers at the expense of female flowers (Robinson and Decker-Walters, 1997). High nitrogen supply and low soil moisture also favor production of male flowers.

Flower production began much earlier in summer squash cultivars (29 DAT) compared with the tropical pumpkin cultivars (44 DAT), then began to decline at 60 DAT when flower production in tropical pumpkin was still very strong. Summer squash is not well adapted to the humid lowland tropics. Declining flower production accompanied an increase in the presence of foliar diseases, especially powdery mildew (Podosphaera xanthii), downy mildew (Pseudoperonospora cubensis), and various potyviruses (Potyvirus). In contrast, the tropical pumpkin cultivars remained relatively healthy with few disease symptoms. This agrees with many years of field observations by one of the authors (L.W.B.).

Traditional cultivars of tropical pumpkin have a vine growth habit and are late flowering. Wessel-Beaver (2005) observed that 'Soler' planted in Puerto Rico (lat. $\approx 18^{\circ} \mathrm{N}$ ) typically begins flowering 55 to $65 \mathrm{~d}$ after planting (DAP) or $\approx 45$ to 55 DAT (assuming 10-d-old transplants). The tropical pumpkin cultivars in our study performed in a similar manner, initiating flowering at $44 \mathrm{DAT}$ for Taína Dorada and E1101-1 and at 51 DAT for Verde Luz. Akter et al. (2013) studied 30 cultivars of tropical pumpkin in Bangladesh (lat. $\approx 24^{\circ} \mathrm{N}$ ) and observed that the first male flower opened from 63 to 88 DAP. In another study of 20 tropical pumpkin cultivars in Bangladesh, the first male flower appeared at 52 to $74 \mathrm{DAP}$ (Ahamed et al., 2011). In Nigeria (lat. $\approx 9^{\circ} \mathrm{N}$ ), anthesis of male flowers began $\approx 8$ weeks after planting (Agbagwa et al., 2007). UPRM has developed tropical pumpkin cultivars with a semibush growth habit and earlier flowering; Taína Dorada is a semibush type. These cultivars can flower as early as 35 DAP (Wessel-Beaver et al., 2006). One author of this study (L.W.B.) has observed that 'Taína Dorada' and 'Verde Luz' flower later under long days, wheras 'Soler' is less sensitive to changes in daylength. In our study, we used the same spacing ( $6 \mathrm{ft}$ between plants) for all cultivars. Planting density can be increased in semibush tropical pumpkin, potentially increasing flower production/ area.

There have been only a few studies made of counts of male flowers/plant in squash and pumpkin. Kiramana et al. (2016) evaluated number of male flowers in 72 cultivars of tropical pumpkin planted in two farms located in Kenya (on the equator). The total number of male flowers per plant ranged from 11 to 197 (mean of 74) during the two seasons of the harvesting period (harvesting began $20 \mathrm{~d}$ after planting). Akter et al. (2013), studying 30 cultivars of tropical pumpkin in Bangladesh, 
observed 49 to 93 (mean of 71.5) male flowers/plant. In our study, total male flowers/plant over the 27 $\mathrm{d}$ of harvest ranged from 48 to 109 for the two summer squash cultivars studied and from 79 to 92 for the three tropical pumpkin cultivars (Table 1), a range similar to other studies.

We found no studies in the literature concerning the weight and length of male flowers of tropical pumpkin. One author of this study (L.W.B.) has worked extensively with squash and pumpkin, particularly tropical pumpkin. Her observations confirm that, in general, flowers of tropical pumpkin are larger than those of summer squash.

Male flower production in tropical pumpkin generally continues up to when the first fruits mature at about 120 DAT. In our study, we limited flower harvest to a 2-month period that ended before fruits were mature. This minimized damage to vines during the final period of fruit maturation, a practice that would be important if a grower wanted to harvest both flowers and fruit. If one assumes an average production of three flowers/plant per day over a 2 -month period, nearly 1000 male flowers can be harvested from 0.1 ha of land. This represents a manageable number of flowers for a small grower to process and market.

SHELF LIFE. Edible flowers continue to respire and transpire after harvest resulting in tissue degradation and water loss. Temperature and altered gas composition, such as that employed with MAP or CAS, can influence both metabolic processes. Temperature, humidity, and permeability of packaging to gas and water vapor are all factors that influence the ability of MAP to extend shelf life. All plastic films, including the PET/PE film used in our study, have some degree of permeability to gas and water vapor. Water vapor molecules do not easily escape from PET packaging because its permeability is relatively low compared with the transpiration rate (Mahajan et al., 2014). PET permeability to $\mathrm{CO}_{2}$ is also low but $\mathrm{O}_{2}$ passes through much more easily. Ideally, a film should allow more $\mathrm{CO}_{2}$ to exit than it lets $\mathrm{O}_{2}$ enter to prevent $\mathrm{CO}_{2}$ levels from becoming too high (Kader and Saltveit, 2002a).
During respiration, stored organic materials (carbohydrates, proteins, fats) are broken down into simple end products with a release of energy, using $\mathrm{O}_{2}$ and producing $\mathrm{CO}_{2}$ during this process (Kader and Saltveit, 2002b). Not considering water vapor, atmospheric air is made up of $21 \% \mathrm{O}_{2}, 78 \% \mathrm{~N}_{2}$, and a small amount of $\mathrm{CO}_{2}(0.04 \%)$ and other gases (Williams, 2020). Lower storage temperature and the presence of $\mathrm{CO}_{2}$ concentrations higher than those normally found in atmospheric air can potentially reduce degradation of flower tissues by reducing the rate of oxygendependent respiration (Kader and Saltveit, 2002a; Reid and Jiang, 2012). For active MAP, the packaging equipment in our study was set to establish the initial percentages of $\mathrm{O}_{2}$ and $\mathrm{CO}_{2}$ at levels that could potentially reduce the respiration rate of pumpkin flowers within the package: $5 \% \mathrm{O}_{2}$ and $11 \% \mathrm{CO}_{2}$ (with $\mathrm{N}_{2}$ completing the volume to $100 \%$ ). Actual (measured) concentrations at day 0 with active MAP were slightly higher: $\approx 6 \%$ to $7 \% \mathrm{O}_{2}$ and $12 \%$ to $13 \% \mathrm{CO}_{2}$ (Fig. 2). This small difference was not thought to be important given that Asiain-Morales et al. (2008) tested summer squash flowers stored at $11 \%$ and $15 \% \mathrm{CO}_{2}$ and both concentrations gave similar positive results. At day 0 under passive MAP, measured levels of $\mathrm{O}_{2}$ and $\mathrm{CO}_{2}$ were as expected $(\approx 21 \%$ and $\approx 1 \%$, respectively) because packages were sealed without further intervention (Fig. 2). Over the following $5 \mathrm{~d}$, respiration of flowers within these packages resulted in the consumption of $\mathrm{O}_{2}$ and release of $\mathrm{CO}_{2}$. Averaged over both storage temperatures, there were large cha-nges in concentrations of $\mathrm{O}_{2}$ and $\mathrm{CO}_{2}$ within packages of passive MAP but far less change with active MAP. With passive $\mathrm{MAP}, \mathrm{O}_{2}$ decreased from an average of $20.9 \%$ on day 0 to $6.6 \%$ on day 5 (a change of $14.3 \%$ ), and $\mathrm{CO}_{2}$ increased from $0.8 \%$ on day 0 to $17.5 \%$ on day 5 (a change of 16.7\%), suggesting a strong rate of respiration of flowers in these packages. In contrast, changes in packages with active MAP, although often significant, were much smaller. Oxygen decreased from $7.3 \%$ on day 0 to $3.4 \%$ on day 5 (a change of 3.9\%) and $\mathrm{CO}_{2}$ increased from $11.9 \%$ on day 0 to $18.0 \%$ on day 5 (a change of 6.1\%). These much smaller changes suggest a relatively lower respiration rate of flowers in packages with active compared with passive MAP.
By the third day of storage in our study, packaged flowers lost an average of $10.7 \%$ to $13.5 \%$ of their initial weight at 5 and $10^{\circ} \mathrm{C}$, respectively (Table 3 ). After $5 \mathrm{~d}$ of storage, flowers lost an average of $\approx 27 \%$ of their initial weight at both 5 and $10^{\circ} \mathrm{C}$. In contrast, Aquino-Bolaños et al. (2013) observed losses of only $2.4 \%$ to $7.7 \%$ by day 8 . The CAS conditions in that study, especially the continuous flow of highly humidified air, likely contributed to the different results.

Despite the lower respiration rate for flowers under active MAP, active MAP only occasionally resulted in flowers with better appearance over a 7 -d storage period (Table 4). Goodquality pumpkin flowers were maintained for a longer period in several previously reported studies compared with our own, but experimental conditions in these studies were substantially different from those in our experiment. Both Asiain-Morales et al. (2008) and Aquino-Bolaños et al. (2013) studied shelf life of summer squash by simulating CAS conditions rather than using MAP. They compared high levels of $\mathrm{CO}_{2}(10 \%$ to $15 \%)$ with atmospheric air as a control. Asiain-Morales et al. (2008) placed unopened flower buds in controlled atmosphere chambers, while Aquino-Bolaños et al. (2013) placed opened flowers in trays inside controlled atmosphere glass containers. In each case, a continuous flow of specific gas composition was maintained over the entire storage period. In our study, no additional interventions were made to change or maintain the internal gas composition of a package once it was sealed. In studies by Asiain-Morales et al. (2008) and Aquino-Bolaños et al. (2013), flowers under sustained high levels of $\mathrm{CO}_{2}(10 \%$ to $11 \%)$ remained marketable for up to $16 \mathrm{~d}$, whereas flowers stored under flowing atmospheric air (control) maintained marketability for $8 \mathrm{~d}$. In most settings (e.g., a supermarket), it seems unlikely that CA conditions used in these previous studies would be practical for storage of pumpkin flowers. Villalta et al. (2004) conducted their study with closed (preanthesis) flowers of summer squash at 2.5 and $5{ }^{\circ} \mathrm{C}$ under passive MAP; these flowers had a shelf life of $7 \mathrm{~d}$. Whereas MAP and temperature conditions in Villalta et al. (2004) were like ours, we 
evaluated open flowers harvested at anthesis, not closed flowers.

In contrast to type of MAP, storage temperature often affected flower shelf life. This was particularly true for 'Taína Dorada' where quality was always better in flowers stored at $5^{\circ} \mathrm{C}$ compared with $10^{\circ} \mathrm{C}$ (Table 4). Lower storage temperatures would be expected to reduce respiration rates and thus flower degradation (Kader and Saltveit, 2002a). It should be noted, however, that results of Expt. 2 suggest that respiration rates, as indirectly measured by changes in $\mathrm{O}_{2}$ and $\mathrm{CO}_{2}$, were not different at the two storage temperatures.

The appearance (quality) of tropical pumpkin flowers was notably better than that of summer squash during the first $5 \mathrm{~d}$ of storage in our study (Table 4). However, flowers of all cultivars deteriorated after $5 \mathrm{~d}$. Deterioration in appearance was mainly due to breakdown of tissue of the corolla, likely due to the combination of oxidation of flower tissues and presence of microorganisms. The tropical pumpkin cultivar that maintained the best flower quality (appearance) over time in our study was Soler, although even it had poor quality at $6 \mathrm{~d}$. This cultivar is the most widely planted cultivar in Puerto Rico and has been trialed with success in Haiti, Hawaii, and Colombia.

Chemical AND NUTRItional ANALYSES. Soluble solids content of fresh tropical pumpkin flowers was comparable to that in studies by AquinoBolaños et al. (2013) on summer squash flowers. In their study soluble solids in samples with passive MAP decreased from $4.57 \%$ to $1.61 \%$ after $8 \mathrm{~d}$ of storage, whereas soluble solids with active MAP decreased to a much lesser degree (from $4.57 \%$ to $4.06 \%$ ). In our study, percent soluble solids also decreased over time, but there were almost no significant differences between packages with passive vs. active MAP (Fig. 3).

The low citric acid content of pumpkin flowers (Fig. 3) suggests that they are a poor source of organic acids. Initial acidity and the decrease in acidity with storage agree with Aquino-Bolaños et al. (2013). The decrease in acidity can be explained by the fact that flowers with low reserve substrate tend to use the organic acids present as a substrate for respiration processes (Teixeira da Silva, 2003). Aquino-Bolaños et al. (2013) also observed an increase in $\mathrm{pH}$ during storage of summer squash flowers. In our study, the increase in $\mathrm{pH}$ after storage was greater at $10^{\circ} \mathrm{C}$ than at $5{ }^{\circ} \mathrm{C}$.

Aquino-Bolaños et al. (2013) observed an ascorbic acid content of $\approx 16.51 \mathrm{mg} / 100 \mathrm{~g} \mathrm{FW}$ for fresh flowers of summer squash. The U.S. Department of Agriculture (USDA) Nutrient Standard Database (Haytowitz et al., 2019) reports that fresh pumpkin flowers have $28 \mathrm{mg} / 100 \mathrm{~g}$ FW of ascorbic acid. The results obtained in this study are similar to the finding of Aquino-Bolaños et al. (2013) where they also observed a decrease in ascorbic acid after storage. Loss of ascorbic acid after storage of minimally processed vegetables can be attributed to the fact that ascorbic acid can be easily oxidized causing it to reduce during refrigerated storage (Howard et al., 1999).

Chen et al. (2015) evaluated the antioxidant activity on 23 edible flowers and observed DPPH values in TE ranging from 21.14 to $599.43 \mu \mathrm{M} / \mathrm{g}$ dry weight, considerably lower than those obtained from our study where TE values ranged from 39 to $94 \mu \mathrm{M} / \mathrm{g}$ FW, equivalent to TE values of 646 to $1570 \mu \mathrm{M} / \mathrm{g}$ dry weight (Fig. 3). When considering each cultivar separately in our study, we observed that packaged pumpkin flowers lost as much as $90 \%$ of their antioxidant activity after $5 \mathrm{~d}$ of storage both with passive and active MAP and under both temperature treatments $\left(5\right.$ and $\left.10^{\circ} \mathrm{C}\right)$.

In fresh flowers Aquino-Bolaños et al. (2013) observed an average phenolic value in GAE of $334.60 \mathrm{mg} /$ $100 \mathrm{~g}$ FW. Li et al. (2014) carried out a study of total phenolic content on 51 edible wild flowers and observed phenolic content in GAE ranging from 111 to $358 \mathrm{mg} / 100 \mathrm{~g} \mathrm{FW}$ (comparable with this study). During storage, there was a reduction in phenolic content (Fig. 3). The content of bioactive compounds such as phenolics, ascorbic acid, and beta-carotene change during developmental processes and senescence (Cavaiuolo et al., 2013). Initial beta-carotene levels were like those found by Seroczyńska et al. (2006) (Fig. 3). They observed beta-carotene levels ranging from 1.01 to $13.35 \mathrm{mg} / 100 \mathrm{~g} \mathrm{FW}$. In this study, several cultivars exhibited an increase in beta-carotene levels during storage. This might be explained by the dehydration (as reflected by weight loss) observed during storage, resulting in increased concentrations of pigments.

In general, male pumpkin flowers are a low source of fats, carbohydrate, and protein. The results obtained here are comparable to that of the USDA Nutrient Standard Database (Haytowitz et al., 2019). It was shown that pumpkin flowers are a good source of mineral content.

Sensory evaluation. A positive impression of a food's sensorial properties is essential to its acceptance by the consumer. The most notable negative comment during the sensorial evaluation concerned lack of saltiness of canned flowers. Little salt was added in the canning process because our objective was to determine how consumers would react to the taste of flowers alone, unmasked by the flavor of salt. This issue should be taken into consideration when developing a canned pumpkin flower product. Although we did not measure color in canned flowers, we noted that they maintained the same orange-yellow color intensity as fresh flowers. The petioles also maintained a bright green color, making for a very attractive presentation in glass jars. Consumer acceptance of fresh and canned pumpkin flowers could be improved by making recipes using these ingredients more widely available.

\section{Conclusions}

Tropical pumpkin is already a popular and widely grown vegetable in lowland tropical areas such as the Caribbean. In these areas many well-adapted cultivars are available. Harvest of male flowers could be done in the same fields where tropical pumpkin is grown for fruit production, potentially providing an additional source of income to growers. The quality of flowers of tropical pumpkin was superior to those of summer squash. The large size of tropical pumpkin flowers also makes them more attractive for human consumption. Production of ample amounts of male flowers of tropical pumpkin presents few problems: the bigger challenge is extending the shelf life of packaged flowers. Additional study is needed to determine whether shelf life can be extended beyond the $5 \mathrm{~d}$ limit we observed. In general, storage temperature had little effect on 
appearance of packaged flowers. However, when we did observe an effect, flower quality (appearance) was better at $5^{\circ} \mathrm{C}$ compared with $10^{\circ} \mathrm{C}$. Active MAP had no consistent positive effect over passive MAP in terms of flower appearance during storage. During storage, chemical parameters such as percent soluble solids, total acidity, ascorbic acid, antioxidant activity $(\mathrm{DPPH})$ and total phenolics decreased, wheraes $\mathrm{pH}$, and sometimes beta-carotene increased. Storage temperature and packaging method (passive or active MAP) had no consistent effect on these changes. Canned flowers offer a viable alternative to the use of fresh flowers. Sensory evaluations suggested that consumers would find both fresh and canned tropical pumpkin flowers to their liking, either as a vegetable alone or as an addition to salads, soups, or other dishes. Tropical pumpkin flowers are available year-round in Puerto Rico and have the potential to contribute added value to Puerto Rico's gastronomic and agricultural economy.

\section{Literature cited}

Agbagwa, I.O., B.C. Ndukwu, and S.I. Mensah. 2007. Floral biology, breeding system, and pollination ecology of Cucurbita moschata (Duch. ex Lam) Duch. ex Poir. varieties (Cucurbitaceae) from parts of the Niger Delta, Nigeria. Turk. J. Bot. 31(5):451-458. 30 Dec. 2021. <https:// journals.tubitak.gov.tr/botany/issues/bot07-31-5/bot-31-5-4-0603-4.pdf> .

Ahamed, K.U., B. Akhter, M.R. Islam, N. Ara, and M.R. Humauan. 2011. An assessment of morphology and yield characteristics of pumpkin (Cucurbita moschata) genotypes in northern Bangladesh. Trop. Agr. Res. Ext. 14(1):7-11, https://doi. org/10.4038/tare.vl4il.4834.

Allende, A., F. Tomás-Barberán, and M.I. Gil. 2006. Minimal processing for healthy traditional foods. Trends Food Sci. Technol. 17(9):513-519, https://doi.org/10. 1016/j.tifs.2006.04.005.

Akter, S., M.G. Rasul, A.K.M. Aminul Islam, and M.M. Hossain. 2013. Genetic variability, correlation and path coefficient analysis of yield and quality traits in pumpkin (Cucurbita moschata Duch ex Poir.). Bangladesh J. Plant Breed. Genet. 26(1):25-33, https://doi.org/10.3329/ bjpbg.v26il.19981.
American Oil Chemists' Society. 2009. Official methods and recommended practices of the AOCS. 6th ed. AOCS Press, Champaign, IL.

Aquino-Bolaños, E.N., T. Urrutia-Hernández, M. López Del Castillo-Lozano, J.L. Chavéz-Servia, and I. Verdalet-Guzmán. 2013. Physicochemical parameters and antioxidant compounds in edible squash (Cucurbita pepo) flower stored under controlled atmospheres. J. Food Qual. 36(5):302-308, https://doi.org/10.1111/jfq.12053.

Asiain-Morales, J.A., N. Guemes-Vera, M.I.R. Santamaría, E.N. Aquino-Bolaños, R. Corona-Velazquez, and J. Meza-Rangel. 2008. Uso de atmósferas controladas en la conservación de flor de calabaza. 27 Oct. 2021. <https://uaeh.edu.mx/ investigacion/icap/LI_GranSem/Norma_ Vera/8.pdf>.

Association of Official Analytical Chemists. 2003. Official methods of analysis. 17th ed., 2nd revision, Vol. II. AOAC, Gaithersburg, MD.

Brand-Williams, W., M.E. Cuvelier, and C. Berset. 1995. Use of a free radical method to evaluate antioxidant activity. Lebensm. Wiss. Technol. 28(1):25-30, https://doi. org/10.1016/S0023-6438(95)80008-5.

Cavaiuolo, M., G. Cocetta, and A. Ferrante. 2013. The antioxidants changes in ornamental flowers during development and senescence. Antioxidants 2(3):132-155, https://doi.org/10.3390/antiox2030132.

Chen, G.-L., S.-G. Chen, Y.-Q. Xie, F. Chen, Y.-Y. Zhao, C.-X. Luo, and Y.-Q. Gao. 2015. Total phenolic, flavonoid and antioxidant activity of 23 edible flowers subjected to in vitro digestion. J. Funct. Foods 17:243-259, https://doi.org/ 10.1016/j.jff.2015.05.028.

Codex Alimentarius. 2011. Código de practicas de higiene para alimentos poco acido y alimentos poco acido acidificados envasado. CAC/RCP 231979. 27 Nov. 2021. <https://www. fao.org/fao-who-codexalimentarius/shproxy $/$ es $/$ ? lnk= l \&url=https $\% 253 \mathrm{~A} \% 25$ 2F\%252Fworkspace.fao.org\%252Fsites\% 252 Fcodex $\% 252$ FStandards $\% 252$ FCXC \%2B23-1979\%252FCXP_023s.pdf $>$.

Di Rienzo, J.A., F. Casanoves, M.G. Balzarini, L. Gonzalez, M. Tablada, and C.W. Robledo. 2019. InfoStat versión 2019. 2 Nov. 2021. <https://www. infostat.com.ar $>$.

Drava, G., V. Iobbi, R. Govaerts, V. Minganti, A. Copetta, B. Ruffoni, and A. Bisio. 2020. Trace elements in edible flowers from Italy: Further insights into health benefits and risks to consumers. Molecules 25(12):2891, https://doi.org/ $10.3390 /$ molecules25122891.
Haytowitz, D.B., J.K.C. Ahuja, X. Wu, M. Somanchi, M. Nickle, Q.A. Nguyen, J.M. Roseland, J.R. Williams, K.Y. Patterson, Y. Li, and P.R. Pehrsson. 2019. USDA national nutrient database for standard reference, legacy release. 2 Nov. 2021. $<$ https://data.nal.usda.gov/dataset/usdanational-nutrient-database-standard-referencelegacy-release $>$.

Howard, L.A., A.D. Wong, A.K. Perry, and B.P. Klein. 1999. $\beta$-carotene and ascorbic acid retention in fresh and processed vegetables. J. Food Sci. 64(5):929-936, https://doi.org/10.1111/j.1365-2621. 1999.tb15943.x.

Instituto de Estadísticas. 2015. Ingreso bruto de la agricultura de Puerto Rico, Apéndice A, p. 4. 2 Nov. 2021. <https:// www.estadisticas.gobierno.pr/iepr/LinkClick. aspx? fileticket $=y$ Tlplq4sUxE\%3d\&tabid= 186>.

Kader, A.A. and M.E. Saltveit. 2002a. Atmosphere modification, p. 229-246. In: J.A. Bartz and J.K. Brecht (eds.). Postharvest physiology and pathology of vegetables. 2nd ed. CRC Press, Boca Raton, FL.

Kader, A.A. and M.E. Saltveit. 2002b. Respiration and gas exchange, p. 7-29. In: J.A. Bartz and J.K. Brecht (eds.). Postharvest physiology and pathology of vegetables. 2nd ed. CRC Press, Boca Raton, FL.

Kiramana, J.K., D.K. Isutsa, and A.B. Nyende. 2016. Evaluation of quantitative yield performance of pumpkin accessions in Kenya using mother trials. Intl. J. Adv. Biol. Res. 6(4):439-447.

Li, A.-N., S. Li, H.-B. Li, D.-P. Xu, X.-R. Xu, and F. Chen. 2014. Total phenolic contents and antioxidant capacities of 51 edible and wild flowers. J. Funct. Foods 6(1):319-330, https://doi.org/ 10.1016/j.jff.2013.10.022.

Lim, J. 2011. Hedonic scaling: A review of methods and theory. Food Qual. Prefer. 22(8):733-747, https://doi.org/ $10.1016 /$ j.foodqual.2011.05.008.

López Pérez, O. 2007. Manejo postcosecha de flor de calabaza a diferentes condiciones de almacenamiento. Thesis, Universidad Autónoma del Estado de Hidalgo, Instituto de Ciencias Agropecuarias, Pachuca, Mexico. 2 Nov. 2021. <https://repository. uaeh.edu.mx/bitstream/bitstream/handle/ 123456789/10664/Manejo\%20postcosecha $\% 20 \mathrm{de} \% 20$ flor.pdf?sequence $=1>$.

Mahajan, P.V., O.J. Caleb, Z. Singh, C.B. Watkins, and M. Geyer. 2014. Postharvest treatments of fresh produce. Phil. Trans. R. Soc. A 372:20130309, https://doi. org/10.1098/rsta.2013.0309. 
McGuire, R.G. 1992. Reporting of objective color measurements. HortScience 27(12):1254-1255, https://doi.org/10. 21273/HORTSCI.27.12.1254.

Milc, J., A. Caffagni, D. Ronga, E. Francia, M. Pasquariello, L. Laviano, V. Mazzamurro, and N. Pecchioni. 2016. Evaluation of Cucurbita pepo germplasm for staminate flower production and adaptation to the frozen food industry. Scientia Hort. 213:321-330, https://doi.org/ 10.1016/j.scienta.2016.10.045.

Nagata, M. and I. Yamashita. 1992. Simple method for simultaneous determination of chlorophyll and carotenoids in tomato fruit. J. Jpn Soc. Food Sci. Technol. 39:925-928. 2 Nov. 2021. <https:// www.jstage.jst.go.jp/article/nskkk1962/39/ 10/39_10_925/_pdf/-char/ja > (summary in English) <http://cse.naro.affrc.go.jp/ mnagata/pigment2.pdf $>$.

Paris, H.S. and J. Janick. 2004. Early evidence for the culinary use of squash flowers in Italy. Chronica Hort. 45(2):20-21. 2 Nov. 2021. <https://www.hort.purdue. edu/newcrop/squashflowers.pdf $>$.

PerkinElmer Corporation. 1996. Analytical methods for atomic absorption spectroscopy. 2 Nov. 2021. <http://wwwl. lasalle.edu/ prushan/Intrumental\%20An
alysis_files/AA-Perkin\%20Elmer\%20guide $\% 20$ to\%20all!pdf $>$.

Reid, M.S. and C.-Z. Jiang. 2012. Postharvest biology and technology of cut flowers and potted plants. Hort. Rev. (Amer. Soc. Hort. Sci.) 40:1-54, https:// doi.org/10.1002/9781118351871.chl.

Robinson, R.W. and D.S. Decker-Walters. 1997. Cucurbits. CAB Intl., New York, NY.

Seroczyńska, A., A. Korzeniewska, J. Sztangret-Wiśniewska, K. Niemirowicz-Szczytt, and M. Gajewski. 2006. Relationship between carotenoids content and flower or fruit flesh colour of winter squash (Cucurbita maxima Duch.). Folia Hort. 18(1):51-61.

Sotelo, A., S. López-García, and F. Basurto-Peña. 2007. Content of nutrient and antinutrient in edible flowers of wild plants in Mexico. Plant Foods Hum. Nutr. 62:133-138, https://doi.org/10.1007/ s11130-007-0053-9.

Teixeira da Silva, J.A. 2003. The cut flower: Postharvest considerations. Online J. Biol. Sci. 3(4):406-442. 2 Nov. 2021. $<$ https://docsdrive.com/pdfs/ansinet/jbs/ 2003/406-442.pdf $>$.

Tripathi, S.K. and N. Tuteja. 2007. Integrated signaling in flower senescence: An overview. Plant Signal. Behav. 2(6):
437-445, https://doi.org/10.4161/psb.2. 6.4991 .

Umiel, N., H. Friedman, M. Tragerman, E. Mattan, and H.S. Paris. 2007. Comparison of some flower characteristics of Cucurbita pepo accessions. Cucurbit Genet. Coop. Rpt. 30:35-37. 2 Nov. 2021. <https://cucurbit.info/wp-content/ uploads $/ 2019 / 03 / \operatorname{cgc} 30-11$.pdf $>$.

Villalta, A.M., M. Ergun, A.D. Berry, N. Shaw, and S.A. Sargent. 2004. Quality changes of yellow summer squash blossoms (Cucurbita pepo) during storage. Acta Hort. 659:831-834, https:// doi.org/10.17660/ActaHortic.2004. 659.108 .

Wessel-Beaver, L. 2005. Release of 'Soler' tropical pumpkin. J. Agr. Univ. P. R. 89(3-4):263-266, https://doi.org/10. 46429/jaupr.v89i3-4.1047.

Wessel-Beaver, L., O. Román-Hernández, and L.W. Flores-López. 2006. Performance of new tropical pumpkin genotypes under varying cultural practices. J. Agr. Univ. P. R. 90(3-4):193-206, https:// doi.org/10.46429/jaupr.v90i3-4.

Williams, D.R. 2020. Earth fact sheet. NASA Goddard Space Flight Center. 22 Nov. 2021. <https://nssdc.gsfc.nasa.gov/ planetary/factsheet/earthfact.html $>$. 